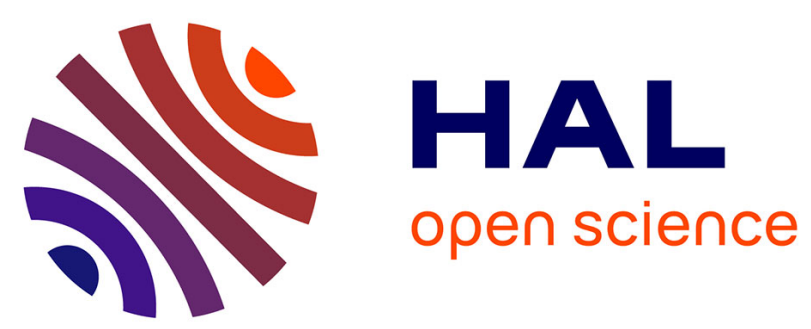

\title{
Leachate flow around a well in MSW landfill: Analysis of field tests using Richards model
}

\author{
R. Slimani, Laurent Oxarango, Badreddine Sbartai, A.-J. Tinet, Olivier \\ Franck, Daniel Dias
}

\section{- To cite this version:}

R. Slimani, Laurent Oxarango, Badreddine Sbartai, A.-J. Tinet, Olivier Franck, et al.. Leachate flow around a well in MSW landfill: Analysis of field tests using Richards model. Waste Management, 2017, 63, pp.122-130. 10.1016/j.wasman.2016.07.048 . hal-02962282

\section{HAL Id: hal-02962282 \\ https://hal.univ-lorraine.fr/hal-02962282}

Submitted on 19 Oct 2020

HAL is a multi-disciplinary open access archive for the deposit and dissemination of scientific research documents, whether they are published or not. The documents may come from teaching and research institutions in France or abroad, or from public or private research centers.
L'archive ouverte pluridisciplinaire HAL, est destinée au dépôt et à la diffusion de documents scientifiques de niveau recherche, publiés ou non, émanant des établissements d'enseignement et de recherche français ou étrangers, des laboratoires publics ou privés.

\section{(ㅇ)(1) $\$$}

Distributed under a Creative Commons Attribution - NonCommercial - NoDerivatives| 4.0 


\title{
Leachate flow around a well in MSW landfill: Analysis of field tests using Richards model
}

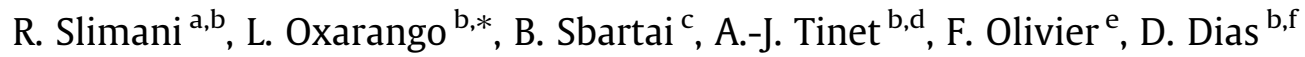 \\ a University of Skikda, Algeria \\ ${ }^{\mathrm{b}}$ Laboratoire d'etude des Transferts en Hydrologie et Environnement (LTHE), Université Grenoble Alpes, BP 5338041 Grenoble Cedex 09, France \\ ${ }^{\mathrm{c}}$ University of Badji Mokhtar-Annaba, Algeria \\ ${ }^{\mathrm{d}}$ Université de Lorraine (ENSG)/CNRS/CREGU, GeoRessources Laboratory, F-54518 Vandoeuvre-lès-Nancy Cedex, France \\ ${ }^{\mathrm{e}}$ ECOGEOS, Geoenvironmental Advisory Services, 5 rue du Jeu de Paume, 62000 Arras, France \\ ${ }_{\mathrm{f}}^{\mathrm{f}}$ Laboratoire Sol, Solide, Structure, Risque (3SR), Université Grenoble Alpes, BP 5338041 Grenoble Cedex 09, France
}

Keywords:

Landfill

Pumping test

Injection test

Richards equation

Numerical modeling

\begin{abstract}
A B S T R A C T
During the lifespan of a Municipal Solid Waste landfill, its leachate drainage system may get clogged. Then, as a consequence of rainfall, leachate generation and possibly leachate injection, the moisture content in the landfill increases to the point that a leachate mound could be created. Therefore, pumping the leachate becomes a necessary solution. This paper presents an original analysis of leachate pumping and injection in an instrumented well. The water table level around the well is monitored by nine piezometers which allow the leachate flow behaviour to be captured. A numerical model based on Richards equation and an exponential relationship between saturated hydraulic conductivity and depth is used to analyze the landfill response to pumping and injection. Decreasing permeability with depth appears to have a major influence on the behaviour of the leachate flow. It could have a drastic negative impact on the pumping efficiency with a maximum quasi-stationary pumping rate limited to approximately $1 \mathrm{~m}^{3} / \mathrm{h}$ for the tested well and the radius of influence is less than $20 \mathrm{~m}$. The numerical model provides a reasonable description of both pumping and injection tests. However, an anomalous behaviour observed at the transition between pumping and recovery phases is observed. This could be due to a limitation of the Richards model in that it neglects the gas phase behaviour and other double porosity heterogeneous effects.
\end{abstract}

\section{Introduction}

Throughout their lifetime, landfills are exposed to rainfall and leachate release due to biodegradation. These phenomena tend to increase the moisture content of waste and potentially to generate a leachate saturated zone. The accumulation of leachate represents serious implications in terms of leaking toward the soil surrounding the landfill, difficulties for gas recovery and slope stability issues (Koerner and Soong, 2000). In order to prevent such situations, the French legislation traditionally limits the leachate saturated fringe to a maximum height of between $300 \mathrm{~mm}$ and $500 \mathrm{~mm}$ (French orders of 31/12/2001 (article 1-11) and 12/01/2006 (article 18)). To meet this regulation, modern French landfills are designed to have a double barrier (passive and active) at their base. An underdrain system is used to collect leachate at

\footnotetext{
* Corresponding author.

E-mail address: laurent.oxarango@ujf-grenoble.fr (L. Oxarango).
}

the lowest point of a landfill cell from where it is drained either by gravity (using buried pipes) or by a forced purge system (using buried pumps). Such a system is in general sufficient to prevent the appearance of a leachate mound. However, some old landfill cells, designed before this regulation, could suffer from a clogged (Fleming et al., 1999; Rowe, 2005) or even missing drainage system resulting in an accumulation of leachate with time at the bottom of the landfill. In such conditions, leachate pumping is a solution that may be applied to reduce the mound. A good understanding of the leachate drawdown dynamics, together with an understanding of relative significance of the Municipal Solid Waste (MSW) characteristics influencing the transient drawdown shape is needed in order to optimize a leachate extraction procedure. There are very few published studies that contain a description and interpretation of pumping tests in landfills. Oweis et al. (1990) performed a pumping test in a landfill using a pumping well and three observations wells (at distance of $8.5 \mathrm{~m}, 22 \mathrm{~m}$ and $61 \mathrm{~m}$ respectively from the pumping well) in order to derive an average hydraulic conductivity of the MSW. Rowe and Nadarajah (1996) studied the impact 
of the seepage in steady state conditions as well as the effect of anisotropy in a landfill using a numerical and an analytical model. They demonstrated that the seepage face may be non-negligible for low permeability landfills or when percolation is important. They also demonstrated that while the MSW is likely to be anisotropic, the impact of the vertical permeability did not prove to be significant in their work. Moreover they also proposed a modification of their model to take into account clogging around the well that may reduce the permeability locally. They used the experimental data of Oweis et al. (1990) for the validation of their model. Al-Thani et al. (2004) expanded this study to transient state conditions. They discussed in particular the importance of the seepage face. Their studies used the numerical model Modflow-Surfact with permeabilities and drainage porosities obtained from experimental studies existing in the literature on MSW landfills. More recently, Olivier et al. (2009) reported a pumping test and its analysis using the same software package. In this study, an adjacent well was used to monitor the effect of pumping on the water table level. These studies are based on a simplified flow model that proved efficient to describe pumping in aquifer systems. In a more general way, several authors suggested that a model based on Richards equation constitutes an appropriate framework to model flow in landfill in order to couple hydro-mechanical phenomena (McDougall, 2007; Hettiarachchi et al., 2009; Feng et al., 2015). Reddy et al. (2013) proposed an alternative approach using the 2-phase Darcy model to describe simultaneously biogas and leachate flow. As long as the biogas is actively extracted, the fundamental description of leachate flow with such a model remains similar to Richards equation. The main advantage of Richards equation is to describe the flow in saturated and unsaturated conditions with a single mass balance equation including a mechanistic description of the water fluxes. It has been selected for the present study since it has not yet been applied to the specific case of saturated flow around a well in a landfill. One goal of the proposed comparison between field scale measurement and numerical modeling is to assess the validity of Richards equation when applied to landfill leachate flow. Recently, this validity has been seriously questioned in the situation of leachate injection. Fellner and Brunner (2010) analyzed field data concerning infiltration. Tinet et al. (2011) studied leachate infiltration in crushed MSW laboratory pilots. Han et al. (2011) studied infiltration in laboratory columns filled by a model waste composed of paper. These studies concluded that Richards equation resulted in a poor agreement between experimental and theoretical data. The heterogeneous behaviour of waste material was better described by more complex models known as double porosity or double permeability flow models.

As far as flow at field scale is concerned, the vertical distribution of saturated liquid permeability should be taken into account. MSW material exhibits strong settlements in landfill due to the mechanical stress applied by the waste mass (primary settlement) and slow deformation occurring with time due to mechanical creep and biodegradation (secondary settlement). These phenomena promote a drastic decrease of the saturated liquid permeability with depth. Several authors have studied this decrease using dedicated oedo-permeameter devices in the laboratory (Bleiker et al., 1995; Chen and Chynoweth, 1995; Powrie and Beaven, 1999; Durmusoglu et al., 2006; Reddy et al., 2009; Stoltz et al., 2010b). Hossain et al. (2009) extended this type of laboratory study in order to measure saturated permeability in waste samples at different stages of biodegradation. The range of reported values spreads between $10^{-3} \mathrm{~m} / \mathrm{s}$ and $10^{-8} \mathrm{~m} / \mathrm{s}$ depending on the test apparatus and the compaction level. A consistent decrease is observed with increasing compression state. Few studies based on field experiment are also reported in the literature. They also present a large discrepancy between $10^{-5} \mathrm{~m} / \mathrm{s}$ (Oweis et al., 1990 ) and $6.1 \cdot 10^{-7} \mathrm{~m} \cdot \mathrm{s}^{-1}$ to $5.4 \cdot 10^{-8} \mathrm{~m} \cdot \mathrm{s}^{-1}$ (Jain et al., 2006). However the range of reported values is consistent with the laboratory measurements. The aim of the study described in this paper was to obtain accurate data on leachate flow in the water table. A dense network of piezometers provided an insight into the flow (whether homogeneous or not) around an operational pumping well. A pumping test was first monitored. Two years later, since the water table level exhibited a significant increase, an injection test was conducted in order to gain a better insight on the effect of permeability decrease with depth. The analysis of these tests was then carried out using a numerical model based on Richards equation including an explicit model of permeability decrease with depth. The objective of the study was to:

- estimate the efficiency of the pumping operation in terms of maximum quasi-stationary pumping rate and well radius of influence.

- propose a straightforward assessment of the capability of Richards equation to describe the flow around a well during pumping and injection at the field scale.

\section{Pumping and injection experiments}

\subsection{Description of the test cell and instrumentation}

The experiments were carried out in one of the cells of a landfill extending over $70000 \mathrm{~m}^{2}$ with an average thickness of $14 \mathrm{~m}$. The study cell (around $10000 \mathrm{~m}^{2}$ ) was operated from 1998 to 2001 and was filled with raw waste (about $75 \%$ of MSW and $25 \%$ of non-hazardous industrial waste). The cap cover of the cell was made up of partially cracked chalky material to a thickness of $1.4 \mathrm{~m}$ which supported a thin layer of vegetative cover. The hydraulic characteristics of the cap cover (chalk material of hydraulic conductivity $>10^{-7} \mathrm{~m} \cdot \mathrm{s}^{-1}$ ) and an average slope lower than $2 \%$ resulted in the infiltration of large quantities of rain water. Unlike the more recent cells designed with a drainage layer at their base (made of tyres and ballasts), the study cell does not benefit from any particular drainage facility, apart from a slope gradient of $2 \%$ at its base. Consequently, a leachate saturated zone developed at the base of the cell.

The well used for pumping and injecting is a fully penetrating well (named PM5) made up of perforated concrete pipe (diameter $=1 \mathrm{~m}$ ) surrounded by an approximately $0.1 \mathrm{~m}$ thick gravel layer. Nine piezometers (namely PZ1 to PZ9) were drilled around the well following a star shaped configuration (Fig. 1). They were arranged on 3 lines allowing measurements to a distance up to $25 \mathrm{~m}$ from the well on the longest line (Fig. 1).

This configuration was aimed at studying the movement of the water table as a function of the radius while at the same time gaining information about the spatial heterogeneity according to the directions of the 3 lines. The piezometers have an internal diameter of $58 \mathrm{~mm}$. They are fully penetrating, except PZ1 that faced technical problems during drilling, and was consequently only screened on $6 \mathrm{~m}$ from the bottom of the cell. The technical problems faced during the drilling of PZ1 also explain why PZ1 is closer to the well $(3.85 \mathrm{~m})$ compared to PZ5 and PZ8 $(5 \mathrm{~m})$. The flow rate was measured using an electromagnetic flowmeter (Endress Hauser Promag 10P25). The leachate level in the piezometers was measured during the experiment with manual level probes (OTT KLT-D model) with an estimated accuracy between 2 and $5 \mathrm{~mm}$. Piezometric levels $\mathrm{W}$ are computed with respect to the supposed horizontal bottom of the cell making appropriate corrections based on surface topography. 


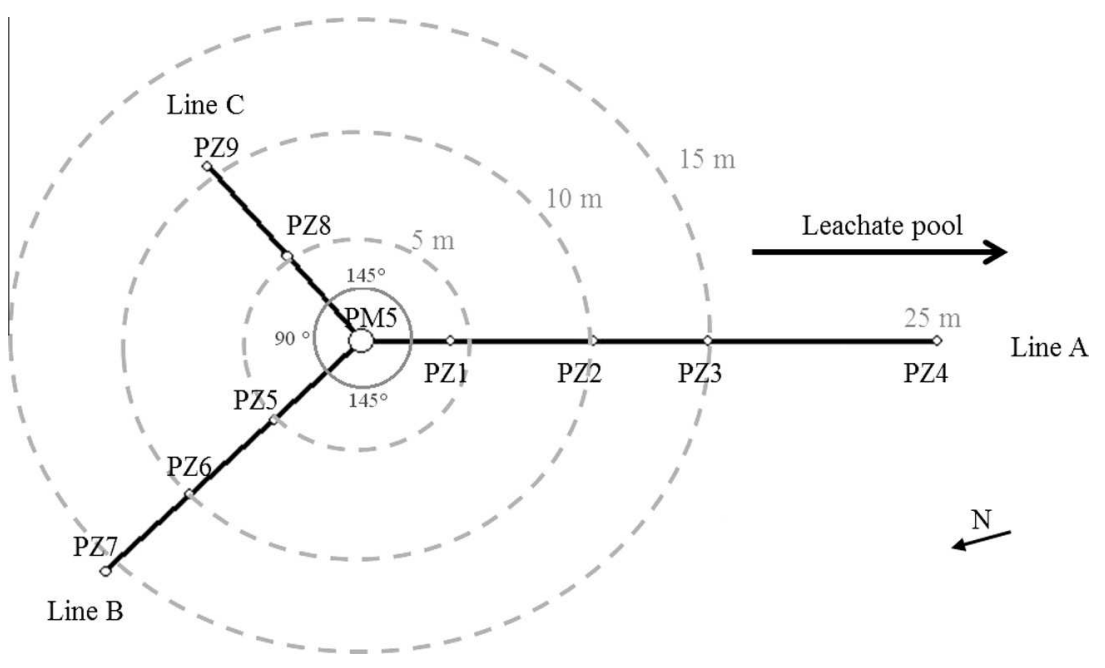

Fig. 1. Well and piezometers locations.

\subsection{Pumping test}

\subsubsection{Presentation of the pumping test}

The pumping test was conducted in July 2010 after a period of two weeks without pumping in well PM5. The leachate water table was stabilized at $7 \mathrm{~m}$ above the bottom of the cell in the studied area before the beginning of the test. The extracted leachate was released in the leachate pool situated $120 \mathrm{~m}$ away from the well. The flow rate and drawdown were monitored during $92 \mathrm{~h}$ with a maximum time interval between two measurements of one hour. The pumping procedure consisted in three distinct phases. During the first phase, a pumping rate of $0.5 \mathrm{~m}^{3} \cdot \mathrm{h}^{-1}$ was selected during $24 \mathrm{~h}$. It was followed by a second pumping phase of $46 \mathrm{~h}$ with a pumping rate of $0.9 \mathrm{~m}^{3} \cdot \mathrm{h}^{-1}$. Finally, the recovery was monitored during $22 \mathrm{~h}$ after the pumping operation stopped. The weather during the experiment remained dry except a small rain event that occurred during the 3 last hours of the final recovery phase. The instantaneous selected and measured flow rates are displayed in Fig. 2a. The pumped volumes are shown in Fig. 2b. Some variations in instantaneous flow rates were observed. This had more significance for the small flow rate $\left(0.5 \mathrm{~m}^{3} \cdot \mathrm{h}^{-1}\right)$ than for the high flow rate $\left(0.9 \mathrm{~m}^{3} \cdot \mathrm{h}^{-1}\right)$. These differences could be attributed to a gas release upstream of the control valve. However, in both cases, the cumulative pumped volumes show little difference in comparison to the expected values.

During the test, the pumping operation stopped twice. After $12 \mathrm{~h}$ (720 min) of pumping, a pipe connection broke. The repair work prevented any flow control and drawdown measurement for one hour. Moreover, $36 \mathrm{~h}(2160 \mathrm{~min})$ after the beginning of the test, the pump broke down and had to be replaced by another pump. During this event, piezometric levels were kept monitored during the two hours necessary for the pump replacement. As a consequence of these disruptions the pumping phases were redefined as shown in Table 1.

\subsubsection{Experimental results}

Results of the pumping test are presented in Fig. 3. Despite the heterogeneous nature of MSW, the evolution of piezometric levels $\mathrm{W}$ with time is smooth. Moreover, they react clearly to the different pumping procedures defined in Fig. 2a.

In the well, the drawdown reaches $1.4 \mathrm{~m}$ (equivalent to a level of $5.6 \mathrm{~m}$ from the bottom of the landfill cell) at the end of the first phase and then reaches a maximum drawdown of $3.8 \mathrm{~m}$ (equivalent to a level of $3.2 \mathrm{~m}$ from the bottom of the landfill cell). One

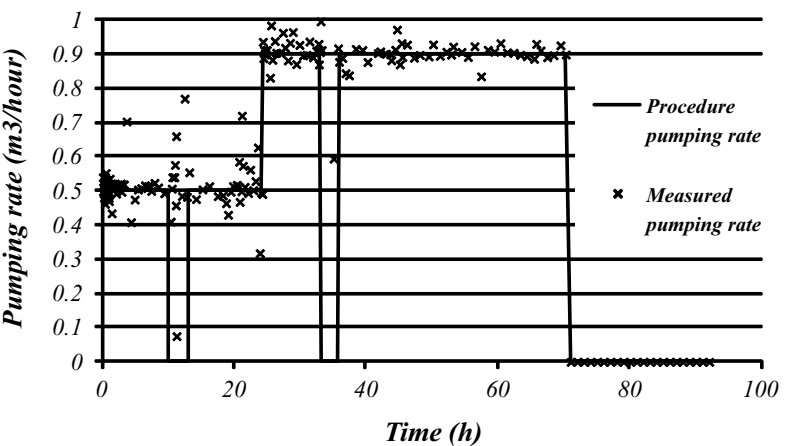

(a)

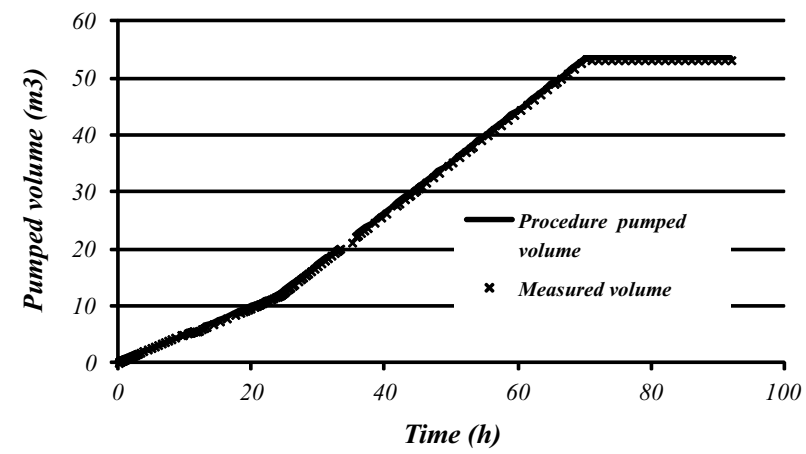

(b)

Fig. 2. Pumping test procedure: (a) procedure and measured instantaneous pumping rates and (b) procedure and measured pumped volumes.

should note that steady conditions or a stationary phase is reached for neither of the two imposed flow rates. After $24 \mathrm{~h}$ at the low flowrate and $48 \mathrm{~h}$ at the higher flow rate, the leachate level in the pumping well still decreases with time and does not exhibit a stabilization trend. Fig. 3a shows the evolution of piezometric level $\mathrm{W}$ in piezometers along line A (see Fig. 1). PZ1 and PZ2 piezometric levels are unexpectedly similar. This may be due to channeling phenomena between the two piezometers that could have been caused by the problematic drilling of PZ1. It can also be observed that the drawdown for PZ4 remains close to zero. The radius of influence of the well within the duration of the test thus remained less than $25 \mathrm{~m}$ and probably very close to $15 \mathrm{~m}$. Conse- 
Table 1

Phases performed during the pumping test.

\begin{tabular}{lllllll}
\hline Phases & Phase 1 & Phase 2 & Phase 3 & Phase 4 & Phase 5 & Phase 6 \\
\hline Time $(\mathrm{h})$ & $0 \mathrm{~h}-12 \mathrm{~h}$ & $12 \mathrm{~h}-13 \mathrm{~h}$ & $13 \mathrm{~h}-24 \mathrm{~h} 20^{\prime}$ & $24 \mathrm{~h} 20^{\prime}-33 \mathrm{~h} 15^{\prime}$ & $33 \mathrm{~h} 15^{\prime}-35 \mathrm{~h} 40^{\prime}$ & $35 \mathrm{~h} 40^{\prime}-70 \mathrm{~h} 15^{\prime}$ \\
Flow rate $\left(\mathrm{m}^{3} \cdot \mathrm{h}^{-1}\right)$ & 0.5 & 0 & 0.5 & 0.9 & 0.9 & 0 \\
\hline
\end{tabular}

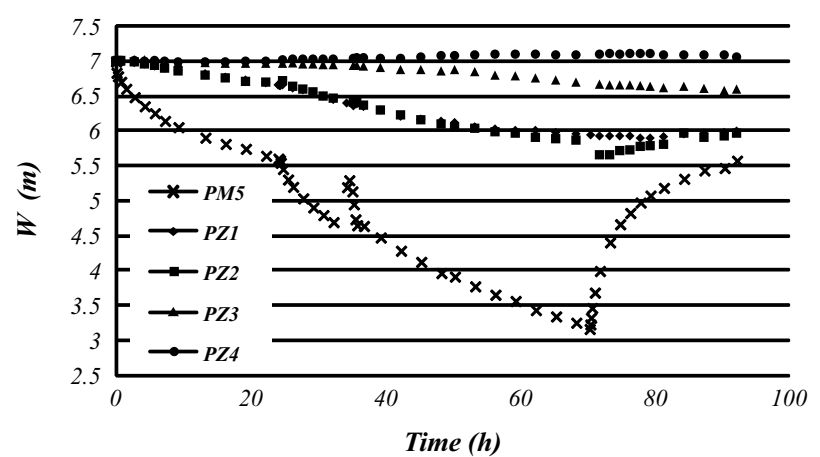

(a)

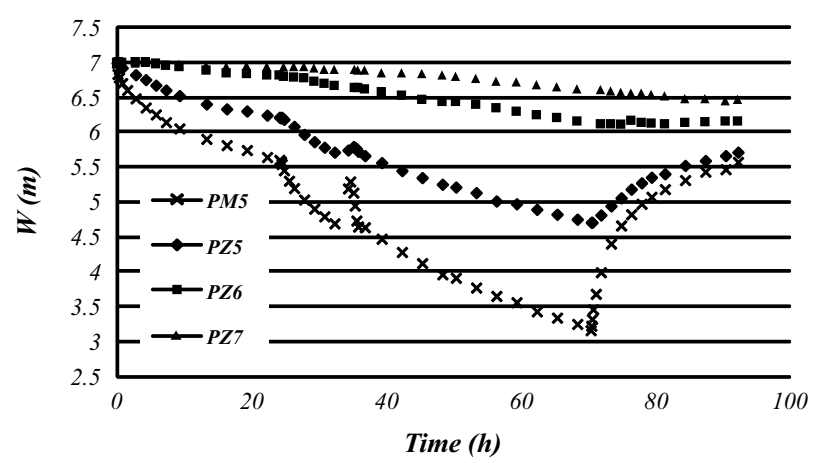

(b)

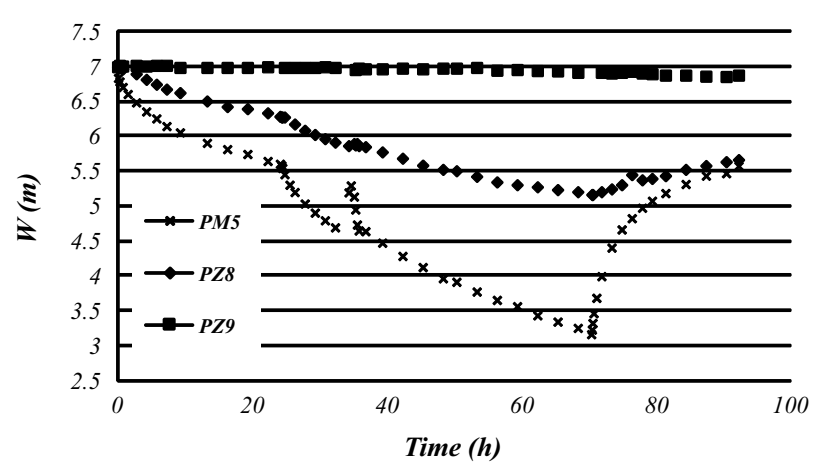

(c)

Fig. 3. Evolution of the piezometric level in the well PM5 and piezometers along the 3 lines during the pumping test: (a) line A, (b) line B and (c) line C.

quently, PZ4 was not affected by the pumping during the experiment. Fig. $3 \mathrm{~b}$ shows the evolution of piezometric level $\mathrm{W}$ in piezometers along line B (see Fig. 1). PZ5 faced a much larger drawdown than PZ1 and reacted to the different phases. PZ5 was also affected by the pump breakdown that happened $12 \mathrm{~h}$ after the beginning of the test. The evolution of piezometric levels along line $B$ is presented in Fig. 4. It exhibits a smooth trend during the entire test. The water table level appears to present a classical cone shape drawdown. Lastly note that PZ6 and PZ7 had similar evolutions to

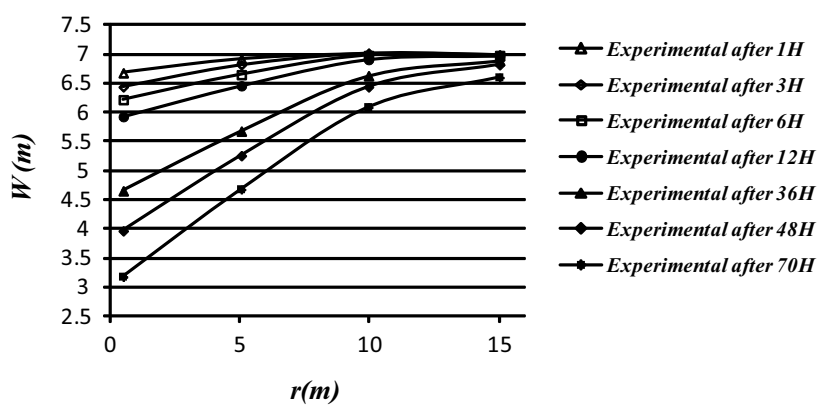

Fig. 4. Radial distribution of piezometric levels at different times along line B.

PZ2 and PZ3 respectively and that they are located at similar distances from the well $(10$ and $15 \mathrm{~m}$ ). Finally, Fig. $3 c$ shows the drawdown - time curve at the different piezometers along Line $C$ (Fig. 1). PZ8 exhibited a similar behaviour to PZ5 whereas PZ9 presented much smaller drawdown than PZ6 and PZ2. It is possible that PZ9 was isolated from the landfill body by plastic elements.

In conclusion, the experimental results tend to demonstrate a globally homogeneous behaviour in terms of leachate pumping and recovery for piezometers PZ2 to PZ8. The radius of influence was lower than $25 \mathrm{~m}$ during the test since PZ4 did not react to the pumping operation. Local heterogeneities and potential issues due to the drilling and landfill configuration lead to anomalous local behaviours for two piezometers out of nine (piezometers PZ1 and PZ9).

\subsection{Injection test}

\subsubsection{Presentation of the injection test}

The injection test was conducted in July 2011 and again after a period of two weeks without pumping from well PM5. This time the leachate water table stabilized at $9.5 \mathrm{~m}$ above the bottom of the cell in the study area before the beginning of the test. The leachate injection was applied using PM5 the same well used for pumping in the first test, and monitoring was carried out using the same nine piezometers installed along the three lines $(A, B$, C) (Fig. 1). The leachate was pumped from an adjacent well located $55 \mathrm{~m}$ away from PM5. The injected flow rate and the piezometric levels were monitored with the same devices used during the pumping test. The leachate was injected at a flowrate of $3.5 \mathrm{~m}^{3} \cdot \mathrm{h}^{-1}$ during $4 \mathrm{~h}$. The relaxation of the water table was then monitored during $22 \mathrm{~h}$. The weather was dry and warm during the test.

\subsubsection{Experimental results}

Results of the injection test are presented in Fig. 5. Since the anomalous behaviour of piezometers PZ1 and PZ9 was also observed during this test, measurements are presented for the four piezometers along line B only. The irregular nature of the well behaviour is simply linked to the short length of the injection pipe. Since the outlet of the pipe was not submerged, splashing induced anomalous readings of the leachate level with the manual level sensor. However, this behaviour disappeared during the relaxation phase and the maximum level reached at the end of the injection 


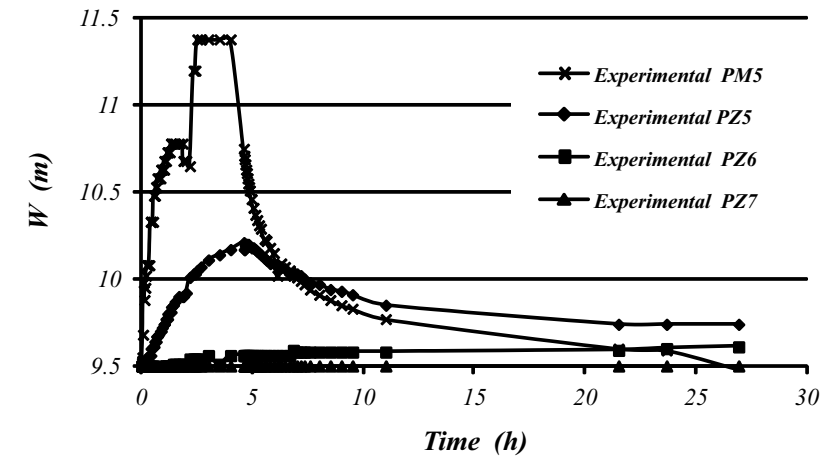

Fig. 5. Evolution of the piezometric level in the well PM5 and piezometers along line B during the injection test.

phase is accurately measured. The evolution of the piezometric level in PZ5 (5 m away from the well) is regular and well defined. The propagation of the piezometric level increase only weakly affected piezometer PZ6 located $10 \mathrm{~m}$ away from PM5.

The main interest of this test is to affect a volume of the waste body significantly above the volume affected by the pumping test. It provides a unique opportunity to apply the same numerical model to these two distinct situations.

\section{Numerical analysis of the pumping test and injection}

\subsection{Model description}

\subsubsection{Constitutive model}

The mass balance of leachate in the waste body is described using the well known Richards equation (Eq. (1)).

$\frac{\partial \theta}{\partial t}=-\nabla \cdot\left(K_{s} k_{r}(\nabla h+1)\right)$

where $\theta\left(\mathrm{m}^{3} \cdot \mathrm{m}^{-3}\right)$ is the volumetric moisture content, $\mathrm{t}(\mathrm{s})$ the time, $K_{s}\left(\mathrm{~m} \cdot \mathrm{s}^{-1}\right)$ the saturated hydraulic conductivity tensor, $k_{r}(-)$ the relative permeability and $h(\mathrm{~m})$ the suction.

Van Genuchten-Mualem equations are used to compute the retention curve $\theta(h)$ and the relative permeability curve $\operatorname{kr}(\theta)$. Introducing the effective saturation of the waste $S_{e}$, these equations reads as:

$S_{e}=\frac{\theta-\theta_{R}}{\theta_{\text {sat }}-\theta_{R}}$

where $\theta_{R}\left(\mathrm{~m}^{3} \cdot \mathrm{m}^{-3}\right)$ is the residual volumetric moisture content and $\theta_{\text {sat }}\left(\mathrm{m}^{3} \cdot \mathrm{m}^{-3}\right)$ is the saturated volumetric moisture content (or the porosity).

$S_{e}=\left(1+(\alpha|h|)^{1 /(1-m)}\right)^{-m}$

where $\alpha\left(\mathrm{m}^{-1}\right)$ and $\mathrm{m}$ are Van Genuchten fitting parameters

$k_{r}=\sqrt{S_{e}}\left(1-\left(1+(\alpha|h|)^{1 /(1-m)}\right)^{-m}\right)^{2}$

The Van Genuchten parameters $\alpha$ and $\mathrm{m}$ and the saturated and residual moisture contents were obtained from experimental measurements on a compacted waste by Stoltz et al. (2012). Even if these vadose zone properties should depend on the waste density (Stoltz et al., 2012; White et al., 2015), these parameters were kept constant to prevent numerical instabilities of the final numerical model. However, a sensitivity analysis showed that they had small influence since the MSW is closed to saturation in this study.

The saturated hydraulic conductivity (or permeability) $K_{s}$ is the key parameter characterizing MSW in this study. The permeability of waste decreases significantly with dry density and thus with depth. Consequently, the saturated hydraulic conductivity of the waste domain was considered as a function of height in the landfill cell (Eq. (5)). This model will be referred to as the stratified model.

$K_{s}=K_{0} \cdot \exp \left(\frac{z-Z_{\max }}{\tau_{z}}\right)$

where $K_{0}\left(\mathrm{~m} \cdot \mathrm{s}^{-1}\right)$ is a reference hydraulic conductivity corresponding to the small compaction state under the cap cover, $\mathrm{z}(\mathrm{m})$ is the height of the considered point, $\mathrm{Z}_{\max }(\mathrm{m})$ is the thickness of the landfill cell and $\tau_{z}(\mathrm{~m})$ is a coefficient describing the evolution with depth. The coefficients $K_{0}$ and $\tau_{z}$ were fitted (see Table 2) to match the relationship obtained from laboratory experiments by Stoltz et al. (2010a,b) as shown in Fig. 6. The empirical exponential curve depending on $\mathrm{z}$ matches satisfyingly the experimental data in the volume concerned by the pumping and injection tests (up to $\mathrm{z}=12 \mathrm{~m}$ ). It was selected since it allows an easy implementation in the software package.

In order to highlight the effect of the permeability stratification, a uniform permeability model is also computed. Considering a homogenous domain, a saturated hydraulic conductivity of $8.57 \times 10^{-6} \mathrm{~m} \cdot \mathrm{s}^{-1}$ was selected since it gave reasonably representation of the pumping test results after an approximate fitting.

\subsubsection{Calculation domain, initial and boundary conditions}

The mathematical model (Eq. (1)-(5)) is implemented in COMSOL Multiphysics V4.2 software package. It is solved on a 2D axisymmetric domain representing the landfill cell around the pumping well PM5. The mesh used for the simulation is refined around the well in order to capture accurately the converging flow in the axisymmetric domain.

The hydrostatic equilibrium, i.e. constant hydraulic head $\mathrm{H}$, is set as initial condition in order to impose the required water table level.

A no flow boundary condition is used at the top and bottom of the domain representing a perfect sealing or neglecting any infiltration in the cap cover or the bottom liner during the duration of tests. A no flow boundary condition is applied at the external side of the domain representing a symmetry (or infinite) condition. A specific model was developed to describe the well boundary condition. A Cauchy boundary condition is applied on the boundary in order to describe the horizontal flow inside the gravel drainage layer surrounding the well and no flow occurring above the leachate level in the well:

$\left\{\begin{array}{l}\text { if } H_{\text {well }} \geqslant z: \quad v=\frac{K_{g r}}{L_{g r}}\left(H_{\text {well }}-H(z)\right) \\ \text { if } H_{\text {well }}<z: \quad v=0\end{array}\right.$

Table 2

Numerical model parameters.

\begin{tabular}{|c|c|c|c|}
\hline Parameters & Values & Parameters & Values \\
\hline Well radius $(\mathrm{m})$ & 0.5 & Stratified model & \\
\hline Well depth (m) & 14 & $\begin{array}{l}\text { Hydraulic conductivity } \\
\text { parameter } \mathrm{K}_{0}\left(\mathrm{~m} \cdot \mathrm{s}^{-1}\right)\end{array}$ & $2 \times 10^{-4}$ \\
\hline $\begin{array}{l}\text { Gravel layer thickness } \\
\text { (m) }\end{array}$ & 0.1 & Depth parameter $\tau_{z}(\mathrm{~m})$ & 3.52 \\
\hline $\begin{array}{l}\text { Gravel hydraulic } \\
\quad \text { conductivity }\left(\mathrm{m} \cdot \mathrm{s}^{-1}\right)\end{array}$ & $10^{-4}$ & & \\
\hline $\begin{array}{l}\text { Saturated moisture } \\
\text { content } \theta_{s}\left(\mathrm{~m}^{3} \cdot \mathrm{m}^{-3}\right)\end{array}$ & 0.45 & Homogeneous model & \\
\hline $\begin{array}{l}\text { Residual moisture } \\
\quad \text { content } \theta_{R}\left(\mathrm{~m}^{3} \cdot \mathrm{m}^{-3}\right)\end{array}$ & 0.3 & $\begin{array}{l}\text { Hydraulic conductivity Ks } \\
\left(\mathrm{m} \cdot \mathrm{s}^{-1}\right)\end{array}$ & $8.57 \times 10^{-6}$ \\
\hline $\begin{array}{l}\text { Van Genuchten } \\
\quad \text { parameter } \mathrm{m}(-)\end{array}$ & 0.25 & & \\
\hline $\begin{array}{l}\text { Van Genuchten } \\
\quad \text { parameter } \alpha\left(\mathrm{m}^{-1}\right)\end{array}$ & 0.6 & & \\
\hline
\end{tabular}




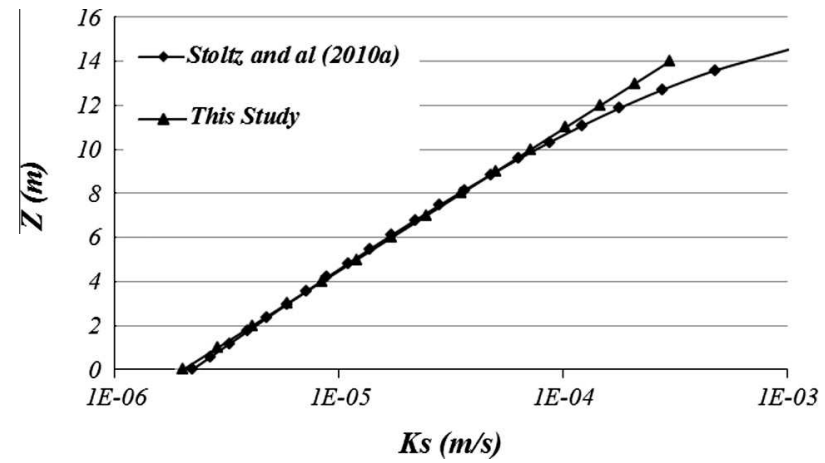

Fig. 6. Evolution of the saturated permeability with depth predicted with the simplified exponential relationship (Eq. (5)) and (Stoltz et al., 2010a,b).

where $v\left(\mathrm{~m} \cdot \mathrm{s}^{-1}\right)$ is the leachate velocity at the boundary, $H_{\text {well }}(\mathrm{m})$ is the hydraulic head (or the leachate depth) inside the well, $K_{\mathrm{gr}}$ $\left(\mathrm{m} \cdot \mathrm{s}^{-1}\right)$ the gravel layer saturated hydraulic conductivity and $L_{g r}$ (m) the gravel layer thickness.

This boundary condition implicitly assumes that no seepage face occurs in the vicinity of the well since no leachate flux can occur above the leachate level in the well. This assumption was selected in accordance to the small flow rate imposed in the pumping test. The same boundary condition was applied in the model for the injection test where the seepage face issue does not arise.

The hydraulic head $H_{\text {well }}$ is computed using the leachate mass balance inside the well with respect to the leachate flux along the boundary.

$\pi R_{\text {well }}^{2} \frac{d H_{\text {well }}}{d t}=-Q_{\text {pump }}-2 \pi R_{\text {well }} \int_{0}^{Z_{\max }} v d z$

where $R_{\text {well }}(\mathrm{m})$ is the well radius and $Q_{\text {pump }}\left(\mathrm{m}^{3} \cdot \mathrm{s}^{-1}\right)$ the pumping flowrate. $Q_{\text {pump }}$ is counted positive for pumping and negative for injection. Its evolution with time is imposed in order to match the experimental condition of each test (see Table 1 for the pumping test case). The differential equations (Eqs. (6) and (7)) are solved simultaneously with Richards equation using the coupled nonlinear solver in the COMSOL Multiphysics software.

\subsection{Results and discussion}

\subsubsection{Influence of the vertical stratification of permeability}

The evolution of experimental and simulated leachate levels in the well are presented for the pumping test (Fig. 7a) and for the injection test (Fig. 7b).

Concerning the pumping test, the experimental behaviour is well restituted well by both the homogeneous and the stratified models. This result is not surprising for the homogeneous model since its permeability was used as a fitting parameter. The validity of Stoltz et al. (2010a,b) set of parameters for permeability is more surprising and should not be seen as a generality since values reported in the literature cover a wider range. The slope of the drawdown curve during the first pumping phase (phases 1-3 in Table 1) is on average underestimated by both numerical models except from the very initial time. None of the model parameters was found able to improve this trend. Moreover, both models tend to a steady state since the slope is decreasing with time toward a stabilized leachate level in the well. This behaviour is classically observed in aquifer pumping. The leachate level decreases in the well if the flux coming from the surrounding water table is lower than the pumping rate. Meanwhile, the overall head gradient between the well and the water table tends to increase promoting an increase of the flux. This two coupled phenomena tend toward a steady state if the pumping rate is small enough to prevent empty-

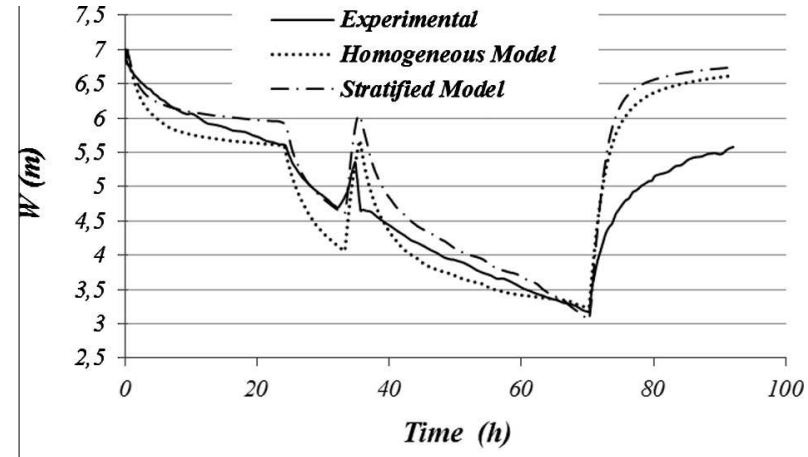

(a)

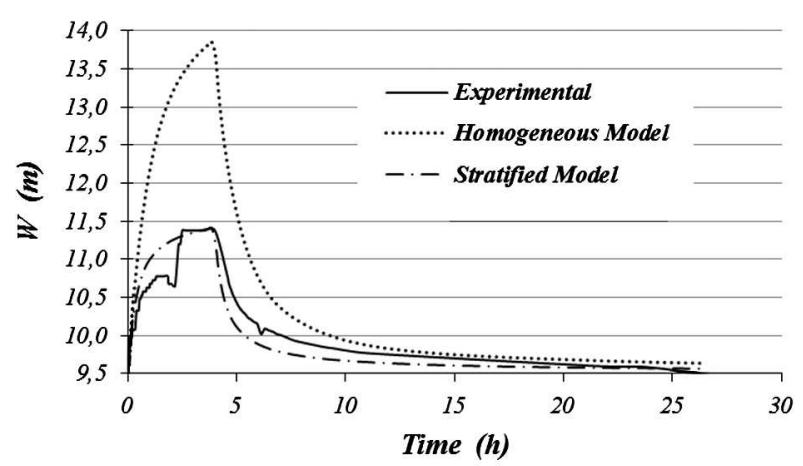

(b)

Fig. 7. Comparison of experiment and simulation for the leachate level in the well: (a) pumping test and (b) injection test.

ing the well. This behaviour is not evidenced by the experimental data. As the second flowrate is imposed (phases 4-6 in Table 1), the drawdown rate increases in all cases. As with the first flowrate, the initial slope is over estimated by both models. Afterwards, the homogeneous model tends to a decreasing drawdown rate with time while the stratified model exhibits an almost constant drawdown rate. The experimental behaviour appears to stand in between the two models and the three curves cross at the end of phase 6 . The difference between the two models is directly linked to the permeability decrease with depth. As the leachate level around the well decreases, the leachate flow tends to occur in a lower permeability zone in the stratified case. The leachate flux to the well thus decreases promoting the leachate level decrease in the well. At the end of phase 6 , the stratified permeability ranges from $2.710^{-5} \mathrm{~m} \cdot \mathrm{s}^{-1}$ for $W=7 \mathrm{~m}$ (away from the well) to $8.810^{-6}$ $\mathrm{m} \cdot \mathrm{s}^{-1}$ for $W=3 \mathrm{~m}$ in the vicinity of the well. This permeability decrease of a factor 3, compared to a decrease of a factor 1.5 at the lowest flowrate, could explain why this trend is much more sensitive at the highest flowrate. The main divergence between model and experiment is observed during the buildup phases occurring when the pump stopped (phase 5 and 7) while it appears to have a very small influence during the first short stop (phase 2). The rate of leachate level increase in the well, as well as in piezometers, is strongly overestimated by both models. Even if this effect is not well understood yet, it will be discussed in Section 3.3.

Concerning the injection test (Fig. 7b), the stratified model appears to reproduce very satisfactorily the experimental data. The model and experimental results during the injection phase cannot properly be compared due to measurement quality. However the level at the end of the injection phase is reproduced accurately. The dynamics after the injection stop are slightly overestimated by the model but it does not exhibit the anomalous trend observed at the end of the pumping test. The uniform 
permeability model drastically overestimates the leachate level rise in the well. During the injection test, the piezometric level ranged from $9.5 \mathrm{~m}$ up to $11.5 \mathrm{~m}$ around the well. According to equation Eq. (5), the permeability respectively ranges from 5.5 $10^{-5} \mathrm{~m} \cdot \mathrm{s}^{-1}$ to $9.810^{-5} \mathrm{~m} \cdot \mathrm{s}^{-1}$. The homogeneous model is then based on a permeability overestimated by a factor between 6 and 10. It drastically limits the flow in the MSW body leading to a quick increase of the leachate level in the well.

These two experiments illustrate the effect of permeability stratification on saturated leachate flow in landfills. The classical Richards model appears to capture the main trends of the experimental behaviour but also suffers some limitations when several drawdown and build up phases are involved. Using a homogeneous permeability could be a good estimate as long as the height of MSW concerned by the water table movement remains small (few meters). However, it should not be used to simulate a significant pumping operation if a thick saturated zone is concerned. In such a case, it is evidently necessary to take into account the permeability decrease with depth.

\subsubsection{Modeling the water table profile}

Radial water table profiles at the end of the pumping operation (after $70 \mathrm{~h} 15^{\prime}$ ) and at the end of the injection operation (after $4 \mathrm{~h}$ ) are plotted respectively in Fig. $8 \mathrm{a}$ and b. The simulated profile is slightly higher than experimental values measured in the piezometers in the pumping case. The general trend is reasonably accurate but the experimental pumping cone is less stiff than the simulated one. The simulated water table profile could be up to $1 \mathrm{~m}$ higher than experimental profile $5 \mathrm{~m}$ away from the well.

In the case of injection, the model is very close to the experimental profile along the line $B$. This observation confirms that the injection test is simulated with a better agreement than the pumping test. Various tests were performed to improve the

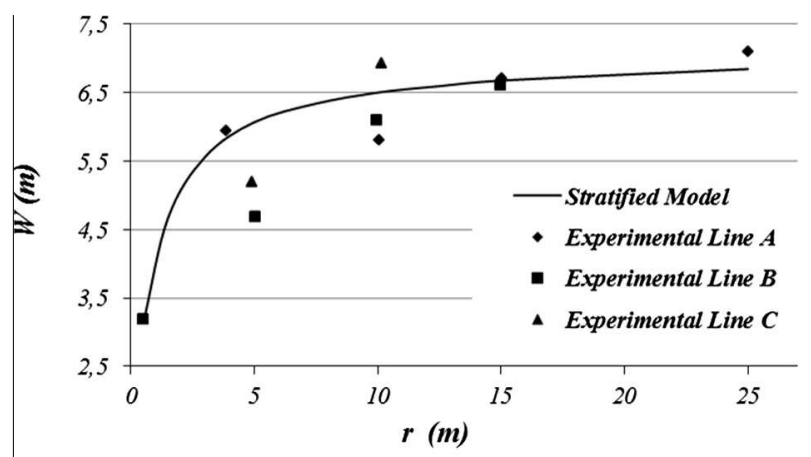

(a)

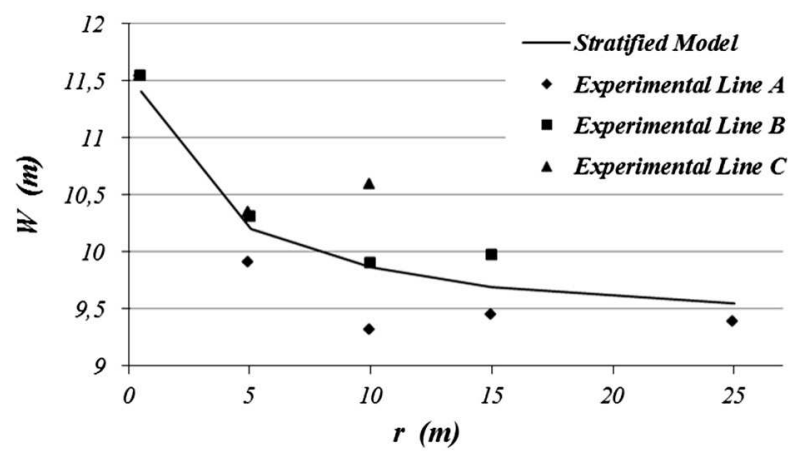

(b)

Fig. 8. Water table profile - (a) at the end of the pumping test and (b) at the end of the injection test. description of the water table profile for the pumping test. The effect of permeability anisotropy was considered but it only had a small effect on the water table profile. On top of that, it was not possible to find a consistent set of hydraulic parameters with an anisotropy ratio of 10 (as proposed by Stoltz et al., 2010b; Munnich et al., 2005) that allowed to preserve both a satisfactory drawdown dynamics in the well and the final leachate level in the well.

\subsubsection{Impact of the variation of Ks with depth during a longer pumping operation}

In this section, the homogeneous and stratified models are used to simulate a constant flow rate pumping situation. The waste properties and computational domain presented in Table 2 are used. At the initial state, the water table level is uniform at $7 \mathrm{~m}$. A $0.9 \mathrm{~m}^{3} \cdot \mathrm{h}^{-1}$ pumping flow rate is imposed. The evolution of the leachate level in the well is presented in Fig. 9.

With the homogeneous model, the drawdown rate tends to decrease with time. The flow of leachate to the well tends to increase when the drawdown cone gets deeper. This behaviour tends to an asymptotic situation for which the leachate level in the well is stable because the flow of leachate from the waste balances the pumping rate. With the stratified model, a similar behaviour is observed during the 20 first hours of pumping. Then, an inflection of the drawdown curve occurs when the drawdown cone reaches lower permeability zones. The leachate flux to the well tends to decrease when the flow around the well only occurs in the deeper, low permeability, layers. This original process related to the distribution of permeability is enhanced by the convergent nature of the axisymmetric flow around the well. Indeed, the lower permeability zones are located around the well in the deepest area of the drawdown cone where the flowrate is high. This result should however be considered with caution since a significant seepage flow in the vicinity of the well may then start to contribute significantly to the total leachate flux to the well.

\subsection{Limitations of the model and prospects for improvement}

Fig. 7a clearly shows a misrepresentation of the buildup phases (phases 4 and 6) during the pumping test. Both uniform and stratified permeability models overestimate systematically the level increase rate in the well when the pumping stopped. The leachate flux from the MSW body to the well is thus overestimated by the model. Despite the satisfying agreement obtained during the pumping phase but also during the injection test, it seems that the Richards model may neglect sensitive processes occurring in the MSW body. At least two distinct origins could be considered to explain the slow flow observed in the field: The relative permeability of the unsaturated zone in the drawdown cone could be

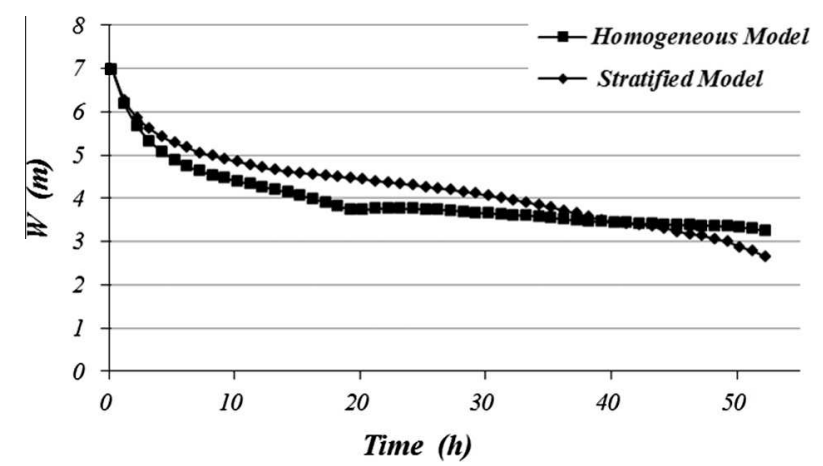

Fig. 9. Impact of the permeability decreasing with depth for a constant flow rate pumping. 
lower during the imbibition phase compared to the initial drainage phase due to the hysteresis of retention curves. The available pore volume accessible to leachate flow during the imbibition could be larger than the drained leachate volume. These two explanations could be consistent with the complete neglecting of the gas phase in Richards model. It is also supported by empirical observation of gas discharge during the pumping test. These observations consisted in bubbling appearing in the well and biogas accumulation in the exhaust pipe (even if this gas was probably originally dissolved in the leachate). It is reasonable to suppose that a significant amount of biogas should be trapped in the saturated zone under impervious plastic layers or in a form of disconnected bubbles. This kind of trapped biogas may reduce the permeability while allowing the porous medium to be saturated in a sense of having a positive pressure head in the liquid phase. Moreover, this biogas should be able to flow easily in the unsaturated zone created by the water table drawdown. This biogas escape would apparently increase the pore volume available for leachate during the imbibition phase. Such an unconventional behaviour has been proposed by Amos and Mayer (2006) in the context of hydrocarbon pollutant biodegradation in an aquifer. They suggested that an unconventional hysteresis should be applied to the retention curve in order to take into account the biogas entrapment in the saturated zone. In order to model such a process, the coupled gas/liquid model proposed by Reddy et al. (2013) is a good candidate. However, it should also include a dedicated hysteretic retention curve model. Such a model would ideally include a specific coupling with a biodegradation model in order to describe the progressive creation of biogas bubbles in the saturated zone. Finally, these considerations remain fully compatible with the concept of a doubleporosity or a double-permeability medium. Unfortunately, a twophase double-permeability model would be extremely hard to apply to a realistic situation due to its numerous parameters.

\section{Conclusion}

This article presented an original well-instrumented pumping and injection tests in a MSW landfill. The pumping test included pumping with two different flow rates followed by a recovery. The drawdown observed in the piezometers and the well was smooth and followed the different phases of the pumping test procedure. Moreover it appeared to exhibit an overall axisymmetric shape around the well even if some heterogeneity was observed on 2 piezometers out of 9 .

This study shows firstly that it is possible to consider a saturated zone in landfills as an unconfined aquifer. The estimated hydraulic conductivity is consistent with literature values for MSW material. Further study of pumping and injection tests, however, shows that the stratification of permeability due to compaction of the material has a significant influence on the response of the water table during pumping operations. Indeed, the flow in the deep layers is much slower due to the low permeability.

While providing a reasonable description of a single pumping phase, the classical Richards model approach failed to describe accurately successive pumping and recovery phases. This limitation may be due to the neglecting of gas phase in this model. The entrapment of biogas in the saturated zone may promote the hysteresis of the retention curve and a change of the porosity available for leachate flow between an imbibition occurring after drainage. Modeling this phenomenon would probably require increasing the level of complexity of existing gas/liquid flow models.

This study has direct implications for the prediction of operational pumping operation in partially saturated landfills. The observed trend implies that a complete drawdown is hardly achievable if vertical wells are used without any bottom drainage system. The observed radius of influence after three days pumping appears to be less than $20 \mathrm{~m}$ for a $4 \mathrm{~m}$ depth drawdown cone. Therefore a dense network of pumping wells would apparently be necessary to control excessive leachate levels efficiently. Even if the study landfill cell was only $14 \mathrm{~m}$ thick, the pumping efficiency appeared to decrease when the drawdown around the well reached the low permeability bottom layers. The maximum pumping rate that could be obtained in the test well is then probably very close to the highest flowrate (about $1 \mathrm{~m}^{3} / \mathrm{h}$ ) applied in the pumping test.

\section{Acknowledgment}

This study was conducted within the framework of the research program "Paraphyme" on sanitary landfill after-care supported by the French Environmental Agency (ADEME).

\section{Appendix A. Supplementary material}

Supplementary data associated with this article can be found, in the online version, at http://dx.doi.org/10.1016/j.wasman.2016.07. 048.

\section{References}

Al-Thani, A.A., Beaven, R.P., White, J.K., 2004. Modelling flow to leachate wells in landfills. Waste Manage. 24 (3), 271-276.

Amos, R.T., Mayer, K.U., 2006. Investigating the role of gas bubble formation and entrapment in contaminated aquifers: reactive transport modelling. J. Contam. Hydrol. 87 (1-2), 123-154.

Bleiker, D.E., Farquhar, G., McBean, E., 1995. Landfill settlement and the impact on site capacity and refuse hydraulic conductivity. Waste Manage. Res. 13, 533554.

Chen, T.H., Chynoweth, D.P., 1995. Hydraulic conductivity of compacted municipal solid-waste. Bioresour. Technol. 51, 205-212.

Durmusoglu, E., Sanchez, I.M., Corapcioglu, M.Y., 2006. Permeability and compression characteristics of municipal solid waste samples. Environ. Geol. $50,773-786$.

Fleming, I.R., Rowe, R.K., Cullimore, D.R., 1999. Field observations of clogging in a landfill leachate collection system. Revue canadienne de géotechnique 36 (4), 685-707.

Fellner, J., Brunner, P.H., 2010. Modeling of leachate generation from MSW landfills by a 2-dimensional 2-domain approach. Waste Manage. 30 (11), 2084-2095.

Feng, S.-J., Cao, B.-Y., Zhang, X., Jiao, Y., 2015. Leachate recirculation in bioreactor landfills considering the stratification of MSW permeability. Environ. Earth Sci. 73 (7), 3349-3359.

Hossain, M.S., Penmethsa, K.K., Hoyos, L., 2009. Permeability of municipal solid waste in bioreactor landfill with degradation. Geotech. Geol. Eng. 27 (1), 43-51.

Han, B., Scicchitano, V., Imhoff, P.T., 2011. Measuring fluid flow properties of waste and assessing alternative conceptual models of pore structure. Waste Manage. 31 (3), 445-456.

Hettiarachchi, H., Meegoda, J., Hettiaratchi, P., 2009. Effect of gas and moisture on modeling of bioreactor landfill settlement. Waste Manage. 29 (3), 1018-1025.

Jain, P., Powell, J., Townsend, T.G., Reinhart, D.R., 2006. Estimating the hydraulic conductivity of landfilled municipal solid waste using the borehole permeameter test. J. Environ. Eng. 132 (6), 645-652.

Koerner, R., Soong, T., 2000. Leachate in landfills: the stability issues. Geotext. Geomembr. 18 (5), 293-309.

McDougall, J., 2007. A hydro-bio-mechanical model for settlement and other behaviour in landfilled waste. Comput. Geotech. 34 (4), 229-246.

Munnich, K., Bauer, J., Fricke, K., 2005. Investigation on relationship between vertical and horizontal permeabilities of MBT wastes. In: Proceeding of Sardinia 2005, International Waste Management and Landfill Symposium, S. Margherita di Pula, Italy.

Olivier, F., Oxarango, L., Mugnier, V., Tinet, A.J., Marcoux, M.A., 2009. Estimating the drawdown of leachate in a saturated landfill: 3D modelling based on field pumping tests. In: Proceeding of Sardinia 2009, International Waste Management and Landfill Symposium, S. Margherita di Pula, Italy.

Oweis, I.S., Smith, D.A., Brian Ellwood, R., Greene, D.S., 1990. Hydraulic characteristics of municipal refuse. J. Geotech. Eng. 116 (4), 539-553.

Powrie, W., Beaven, R.P., 1999. Hydraulic properties of household waste and implications for landfills. Proc. ICE - Geotech. Eng. 137 (4), 235-247.

Reddy, K.R., Hettiarachchi, H., Parakalla, N., Gangathulasi, J., Bogner, J., Lagier, T., 2009. Hydraulic conductivity of MSW in landfills. J. Environ. Eng. 135 (8), 677683. 
Reddy, K., Kulkarni, H., Khire, M., 2013. Two-phase modeling of leachate recirculation using vertical wells in bioreactor landfills. J. Hazard. Toxic Radioactive Waste 17 (4), 272-284.

Rowe, R.K., Nadarajah, P., 1996. Estimating leachate drawdown due to pumping wells in landfills. Can. Geotech. J. 33, 1-10.

Rowe, R.K., 2005. Long-term performance of contaminant barrier systems. Geotechnique 55 (9), 631-678.

Stoltz, G., Gourc, J.-P., Oxarango, L., 2010a. Characterization of the hydromechanical parameters of a MSW. Waste Manage. 30 (8-9), 1439-1449.

Stoltz, G., Gourc, J.-P., Oxarango, L., 2010b. Liquid and gas permeability of unsaturated MSW under compression. J. Contam. Hydrol. 118 (1-2), 27-42.
Stoltz, G., Tinet, A.-J., Staub, M.J., Oxarango, L., Gourc, J.-P., 2012. Retention properties of MSW in relation to compression. J. Geotech. Geoenviron. Eng. 138 (4), 535-543.

Tinet, A.-J., Oxarango, L., Bayard, R., Benbelkacem, H., Stoltz, G., Staub, M.J., Gourc, J.P., 2011. Experimental and theoretical assessment of the double porosity behaviour in a waste body during leachate infiltration. Waste Manage. 31 (8), 1797-1806.

White, J., Zardava, K., Nayagum, D., Powrie, W., 2015. Functional relationship for the estimation of Van Genuchten parameter values in landfill processes models. Waste Manage. 38, 222-231. 